\title{
Speleotourism in Slovenia: balancing between mass tourism and geoheritage protection
}

https://doi.org/10.1515/geo-2018-0027

Received March 13, 2018; accepted June 28, 2018

\begin{abstract}
Slovenia is considered as the cradle of karst geotourism as cave tourism started there as early as the Middle Ages. To date more than 12,000 caves were discovered from which 22 have the status of tourist caves. From these, 10 were assessed using the M-GAM model (Modified Geosite Assessment Model) to gain information for better future management strategies. The results show that visitors of Slovenian tourist caves mostly appreciate their natural values, as they prefer caves without major tourism infrastructure and they pay attention to their protection status. The model also confirmed that the two most important tourist caves (Postojna Cave and Škocjan Caves) have the leading geotourism role and that the management of tourist caves via a regional park as is the case of Škocjan Caves is an example of good practice.
\end{abstract}

Keywords: geoheritage, geotourism, sustainable tourism, tourist caves, speleology, M-GAM, Slovenia

\section{Introduction}

The concept of geotourism was introduced in the early 1990's. It was defined as providing facilities and interpretation services to help tourists to acquire knowledge and understanding of "geosites", i.e. geological or geomorphological sites with recognised value $[1,2]$.

The background of geotourism may be related to caves [3]. Caves were the earliest tourist attractions, and nowadays one of the most appreciated geotourism desti-

J. Tičar: Anton Melik Geographical Institute, Research Centre of the Slovenian Academy of Sciences and Arts, Novi trg 2, 1000 Ljubljana, Slovenia, E-mail: jure.ticar@zrc-sazu.si

M. Breg Valjavec, M. Zorn: Anton Melik Geographical Institute, Research Centre of the Slovenian Academy of Sciences and Arts, Novi trg 2, 1000 Ljubljana, Slovenia

N. Tomić, S. B. Marković, M. B. Gavrilov: Department of Geography, Tourism and Hotel Management, Faculty of Sciences, University of Novi Sad, Trg Dositeja Obradovića, 21000 Novi Sad, Serbia nations in the world [4]. In Slovenia, which is acknowledged as "the cradle of karst geotourism" cave tourism started as early as the Middle Ages when visiting caves was popular either because of curiosities or because of religious reasons (pilgrimages). The world's first tourist cave, meaning that it was necessary to pay for the entrance, was the Vilenica Cave located on the Kras (Karst) Plateau (SW Slovenia), for which it is documented to be a source of income even before $1633[5,6]$. In Germany, the Baumannshöle Cave had guided visits already in 1648 , as well as a conservation and a controlled number of visitors' management plan as early as 1668 [7].

Although tourism is primarily an economic activity considering the use of caves, the focus of geotourism and thus cave tourism has to be conservation of cave environment. Connectivity between the underground and surface makes karst systems especially vulnerable and their sustainability is threatened by increasing human development [8]. Recognizing this problem, the IUCN has formulated guidelines for the protection of caves and karst, and for sustainable tourism in protected areas [9]. The tourist caves are under pressure of large numbers of tourist that potentially alter the local climatic and environmental conditions of the cave system [10, 11]. To ensure the acceptability of tourist influence on cave environment it is necessary to monitor relevant parameters in tourist caves [12]. Through evaluation a carrying capacity for individual tourist cave should be estimated [13-15].

According to Zhang \& Jin [16], there are around 800 tourist caves in the world. The estimated number of visits in 197 tourist caves had revealed that more than 25 million people visit them each year [17]. Tourist caves are most attractive in Europe ( $48 \%$ of visits), followed by Asia (36\% of visits) whereas North America and other continents have a share of $8 \%$ of visits (Fig. 1). Rough estimation of income from cave tourism is more than 2.3 billion US $\$$ per year [17], whereas around 100 million people are directly or indirectly affected by the income of cave tourism [18].

In the paper, the focus is given on tourist caves of Slovenia. Following European and global trends in more environmentally friendly tourism activities, sustainable paradigm and specific management models about geo- 


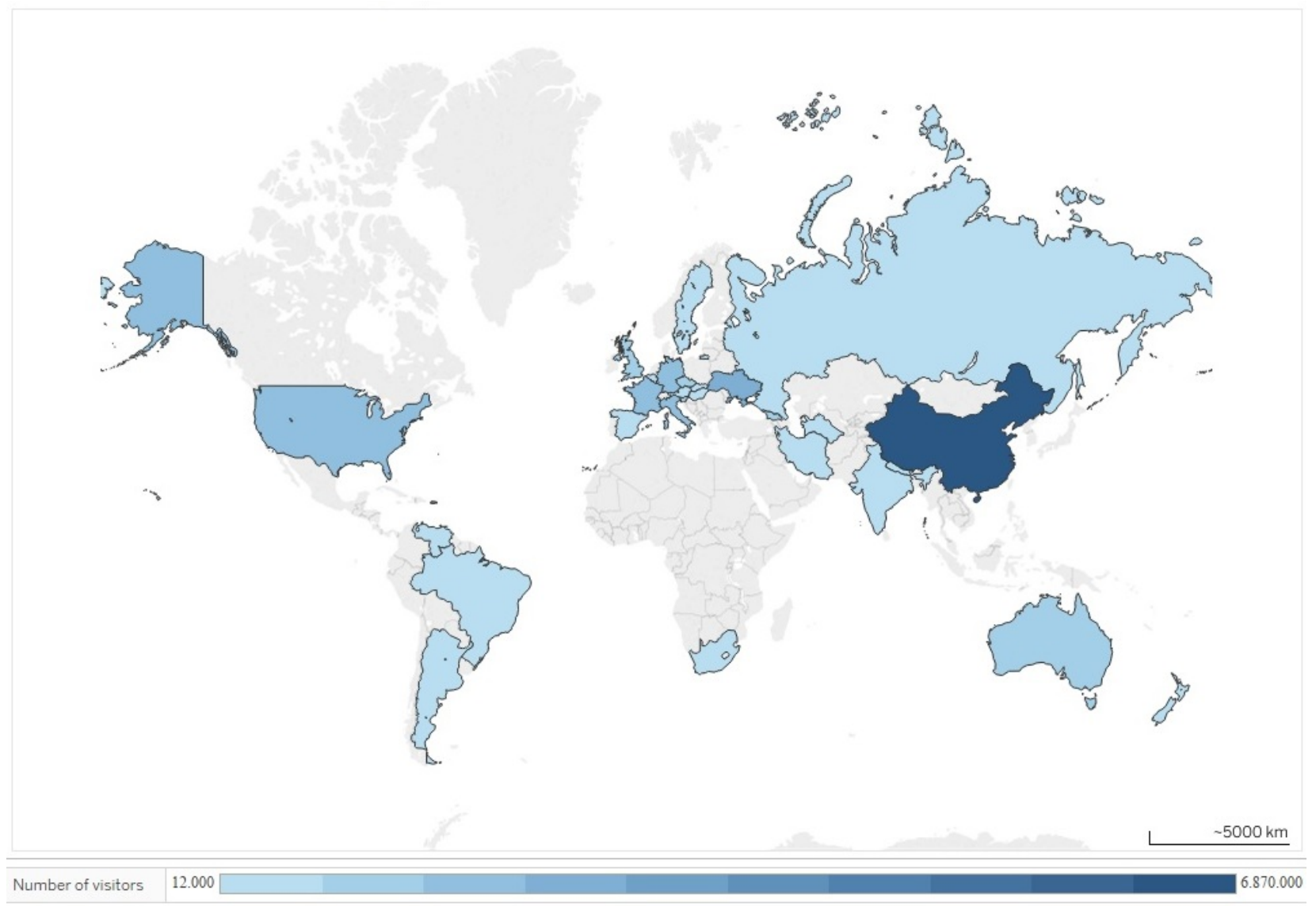

Figure 1: Worldwide distribution of visits in tourist caves per year (adapted from [17]).

heritage and geotourism in Slovenia were implemented through the Slovenian Strategy of Sustainable Growth [19]. The management of caves is strictly regulated according to the Underground Cave Protection Act, because all caves in Slovenia (app. 12,000) are defined as natural heritage of national importance and are owned by the state. The law defines the activities in caves, mostly outlining the prohibited impacts on cave environment. Some regulations have also been applied for tourist activities, due to the commercial use and adaptation of the tourist caves passages.

Good economic (e.g., promotional activities) and as well mismanagement practices (e.g., the effects of tourist paths on cave environment, quality of guide service) can be recognized through the annual frequency of visitors among Slovenian tourist caves and consequently annual income. Based on the data from annual reports for 2016, the Postojna Cave, the biggest tourist attraction in Slovenia, was visited by 689,608 tourists [20], while Škocjan Caves, the only cave system in Slovenia that is under the auspices of UNESCO, had over 145,000 registered visitors [21]. In the Postojna Cave, the economic model prevails, whereas Škocjan Caves are more oriented towards protection of the environment, being the UNESCO world heritage site since 1986.

Already in $19^{\text {th }}$ century tourist caves in present-day Slovenia (in that time in Habsburg Monarchy) were at the top of world cave tourism destinations having the most contemporary technological equipment (e.g., electric illumination and underground train in the case of Postojna Cave), developed promotion and efficient marketing which reflected in good financial income [22].

Nevertheless, an overview of the Slovenian cave tourism shows that some smaller tourist caves are not of such interest for tourists as they were in the past. It means that not only natural beauty, aesthetic or scientific role are necessary for a successful development of geotourism in caves.

The aim of the study was to recognize weaknesses and opportunities of smaller touristic caves and to define the possible management models for the development of successful sustainable geotourism destinations with a primary goal in the conservation of cave heritage. By using the M-GAM (Modified Geosite Assessment Model) model for geosite assessment [23] the management of two suc- 
cessful geotourism cave destinations (Postojna Cave and Škocjan Caves) was compared with management practices of eight smaller and touristically less developed caves (Dimnice Cave, Divača Cave, Pekel Cave, Kostanjevica Cave, Križna Cave, Snežna Cave, Vilenica Cave, Županova Cave). The results of the analysis provide information about possible fields of improvement and to identify which areas require more attention and better management in the future in order for this areas to become a better-known cave tourism destination which could gain the interest of larger number of tourists.

\section{Materials and Methods}

\subsection{Study sites}

According to the Underground Cave Protection Act, 22 caves in Slovenia are designated as tourist caves. Most important tourist caves are managed by a private company (e.g., Postojna Cave) or within a regional park (e.g., Škocjan Caves), nevertheless most of the smaller tourist caves are managed by local caving or tourist societies. The Ministry of the Environment and Spatial Planning gives the manager of a tourist cave a concession with guidelines and restrictions of management. It is worth mentioning that implementation of concession system has been poorly adapted, due to the lack of regulatory provisions. Despite the formal recognition of tourist caves within abovementioned act, some other caves in Slovenia have nowadays been used as a polygon for extreme tourism and adrenaline activities, which is poorly regulated within the act. Our study focused on 10 tourist caves (Table 1, Fig. 2), i.e. the most representative according to the importance of the cave geotourism within local and national tourism resources.

The Dimnice Cave is located in the Podgrajsko podolje, a Low Dinaric karst plateau in SW Slovenia near the Markovščina settlement. The surrounding surface is characterised with numerous dolines and blind valleys at the contact of flysch and limestone rocks at the edge of Kras Plateau [5]. The cave was discovered in 1904 and has a 6,020 m of mostly horizontal passages, with around 1,000 $\mathrm{m}$ of tourist paths [24]. Cave is famous for its mist that is appearing on the entrance due to the circulation of warmer air in the colder period of the year. The cave is also known for its large chambers with big flowstone formations and the underground river. The cave is under the management of a local caving society (Dimnice Koper Caving Society) and has around 2,400 tourist visits per year [5].
Table 1: Main characteristics of studied caves.

\begin{tabular}{|c|c|c|c|c|c|}
\hline Name of the cave & $\begin{array}{l}\text { Length } \\
\text { of the } \\
\text { cave }(\mathrm{m})\end{array}$ & $\begin{array}{l}\text { Length of } \\
\text { the tourist } \\
\text { path (m) }\end{array}$ & Type of karst & $\begin{array}{l}\text { Cave } \\
\text { manager }\end{array}$ & $\begin{array}{l}\text { Number } \\
\text { of visitors } \\
\text { per year }\end{array}$ \\
\hline Dimnice Cave & 6,020 & 1,000 & $\begin{array}{l}\text { Low Dinaric } \\
\text { karst plateau }\end{array}$ & $\begin{array}{l}\text { Local caving } \\
\text { society }\end{array}$ & 2,400 \\
\hline Divača Cave & 672 & 672 & $\begin{array}{l}\text { Low Dinaric } \\
\text { karst plateau }\end{array}$ & $\begin{array}{l}\text { Local caving } \\
\text { society }\end{array}$ & 1,900 \\
\hline Pekel Cave & 1,500 & 400 & $\begin{array}{l}\text { Isolated } \\
\text { Prealps karst }\end{array}$ & $\begin{array}{l}\text { Local tourist } \\
\text { society }\end{array}$ & 14,800 \\
\hline Kostanjevica Cave & 1,871 & 200 & $\begin{array}{l}\text { High Dinaric } \\
\text { karst plateau }\end{array}$ & $\begin{array}{l}\text { Local caving } \\
\text { society }\end{array}$ & 10,300 \\
\hline Križna Cave & 8,273 & 600 & $\begin{array}{l}\text { Low Dinaric } \\
\text { karst plateau }\end{array}$ & $\begin{array}{l}\text { Local caving } \\
\text { society }\end{array}$ & 2,200 \\
\hline Postojna Cave & 24,120 & 5,000 & $\begin{array}{l}\text { Low Dinaric } \\
\text { karst plateau }\end{array}$ & $\begin{array}{l}\text { Private } \\
\text { company }\end{array}$ & 689,000 \\
\hline Snežna Cave & 1,327 & 500 & $\begin{array}{l}\text { High Dinaric } \\
\text { karst plateau }\end{array}$ & $\begin{array}{l}\text { Local caving } \\
\text { society }\end{array}$ & 3,400 \\
\hline Škocjan Caves & 6,310 & 2,300 & $\begin{array}{l}\text { Low Dinaric } \\
\text { karst plateau }\end{array}$ & $\begin{array}{l}\text { Regional } \\
\text { Park }\end{array}$ & 145,000 \\
\hline Vilenica Cave & 841 & 450 & $\begin{array}{l}\text { Low Dinaric } \\
\text { karst plateau }\end{array}$ & $\begin{array}{l}\text { Local caving } \\
\text { society }\end{array}$ & 11,500 \\
\hline Županova Cave & 710 & 327 & $\begin{array}{l}\text { Low Dinaric } \\
\text { karst plateau }\end{array}$ & $\begin{array}{l}\text { Local tourist } \\
\text { society }\end{array}$ & 5,300 \\
\hline
\end{tabular}

The Divača Cave is located in the south-eastern part of Kras Plateau in the SW Slovenia near town of Divača. In the geological past Divača Cave was a part of Reka River system that also carved the underground canyon of Škocjan Caves [25]. The cave was discovered in 1884 and has been soon after arranged for tourist visits. With only $672 \mathrm{~m}$ of horizontal passages [26] that are completely accessible for tourists it's the smallest among the caves included in our study. The cave is famous for its flowstone formations. It attracted some important or famous visitors such as the Austro-Hungarian heir to the throne Rudolf or psychiatrist Sigmund Freud. In the past, cave management had some negative impacts on the cave using slag from steam locomotives for grounding of tourist paths. This problem is being resolved within restoration process in recent years. The cave is under the management of a local caving society ( $D i$ vača Gregor Žiberna Caving Society) and has around 1,900 tourist visits per year [5].

The Pekel Cave is located in the isolated karst of Ponikve Plateau in the NE Slovenia near the Šempeter settlement. The cave is characterised by a relatively large water passage with a total length of $1,500 \mathrm{~m}$ [26]. It has been discovered already in the second half of $19^{\text {th }}$ century and arranged for tourist visits, but this diminished already around 1880. In 1973, the cave was rearranged and around $400 \mathrm{~m}$ was opened for tourism. Since the cave is relatively long and rich in flowstone formation compared to other caves in the region it has attracted attention of numerous tourists. The cave is under the management of a local tourist society (ك̌empeter Tourist Society) and has around 14,800 tourist visits per year [5]. 


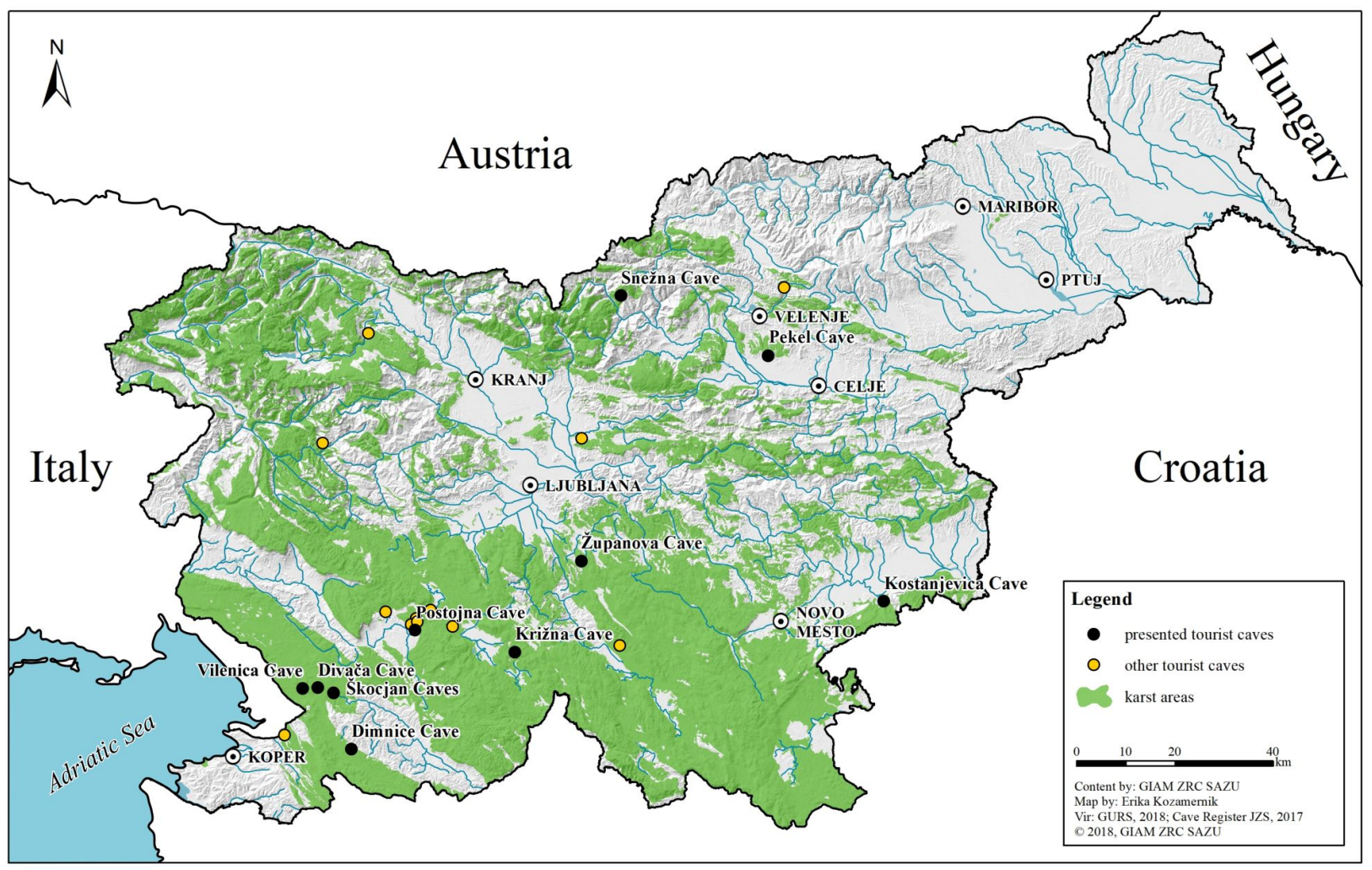

Figure 2: The location of tourist caves included in the study.

The Kostanjevica Cave is located at the foot of Gorjanci Hills in SE Slovenia near the town of Kostanjevica na Krki. The cave was discovered in 1937 and has $1,871 \mathrm{~m}$ of passages [26] with around $200 \mathrm{~m}$ of tourist paths. The cave is famous for its large and decorated chambers, being also an important habitat for Greater horseshoe bats (Rhinolophus ferrumequinum) that gather in colonies. The cave was first opened for tourism already in 1937, being rearranged in 1971, 1984 and 1995. The cave is under the management of a local caving society (Kostanjevica na Krki Caving Society) and has around 10,300 tourist visits per year [5, 27].

The Križna Cave is located at the rim of world renowned Cerknica (karst) Polje in S Slovenia near Lož settlement. The cave was already visited in 1832 and reopened for tourism several times after WWI. It has $8,273 \mathrm{~m}$ of passages [26] of which around $600 \mathrm{~m}$ are arranged for regular tourist visits. Križna Cave is considered one of the most attractive tourist caves in Slovenia, due to the large underground lakes with clear water that were formed behind flowstone dams and highly decorated with flowstone formations. One of the tourist attractions are also the cave bear remains (bones) with numerous findings. The tourist arrangement also includes guided visits of the cave with boats, but the number of visits has been strongly regulated and only small groups are allowed. The cave is under the management of a local caving society (Križna Cave Caving Society) and has around 2,200 tourist visits per year [5].

The Postojna Cave is located at the ponor of Pivka River in SW Slovenia near the town of Postojna. The cave was already occupied by prehistoric man, but first evidences of visits date back to $13^{\text {th }}$ century. Postojna Cave was long considered as the longest cave in Slovenia with more than $24 \mathrm{~km}$ of passages [26] of which nowadays around $5 \mathrm{~km}$ are arranged for tourism. After 1818 when the passage to the greater parts of the cave was discovered, tourism began to flourish. The construction of railway from Vienna to Trieste in the middle of $19^{\text {th }}$ century had a great impact on the number of visitors, followed by the underground railway in 1872 and installation of electricity in 1884. Attractiveness of the Postojna Cave with its flowstone formation, underground river, train, arranged paths, biodiversity and well-established promotional activities soon placed it on the map of the world's most visited tourist caves with its peak at the end of 1990's when nearly 1 million of tourists per year visited the cave. After the breakup of Yugoslavia, the number of tourists dropped significantly, but has been increasing constantly ever since. The cave is nowadays managed by a private company (Posto- 
jnska jama, d. d.) and the Postojna Cave Park with Vivarium, Expo exhibition, different cultural events and connection with the Predjama Castle attracts more than 1 million tourists yearly from which more than 689,000 tourists visit the cave itself $[5,20,28]$.

The Snežna Cave is located on the Raduha Mountain in N Slovenia near the Luče settlement. With the entrance at $1,556 \mathrm{~m}$ a.s.l., it is considered as the highest tourist cave in Slovenia. Being the classical alpine cave, one of the main attractions of the Snežna Cave are ice formations in the Entrance Hall. The cave was discovered in 1981 and has 1,327 $\mathrm{m}$ of generally horizontal passages [26] of which around $500 \mathrm{~m}$ are arranged for tourism since 1990. The main passage is relatively large and decorated with flowstone formations [5]. Recent scientific discoveries focusing on the cave sediments revealed the importance of the cave in understanding and dating of a process of Alpine uplifting [29]. The cave is under the management of a local caving society (Prebold Caving Society) and has around 3,400 tourist visits per year [30].

The Škocjan Caves are located at the eastern edge of Kras Plateau in SW Slovenia near the town of Divača. Picturesque surface represented by a ponor of Reka River (Fig. 3), numerous collapsed dolines, smaller karst surface features and biodiversity were the reason for the establishment of Škocjan Caves Regional Park in 1996. First tourist paths were made already in 1823 . Following the great explorations of the $19^{\text {th }}$ century, tourist numbers increased rapidly in a period between 1884 and 1906 when most of the paths through Škocjan Caves were completed [5]. Today 6,310 m of passages are known [26]. Škocjan Caves are listed in the UNESCO's list of natural and cultural world heritage sites and on the international Ramsar list of wetlands, as first underground wetland in the World, due to its rich underground and terrestrial fauna and flora. More than 145,000 tourist visits them each year [21] with an increasing trend.

The Vilenica Cave is located in the south-eastern part of Kras Plateau in SW Slovenia near Lokev settlement. It has been known as the world's oldest tourist cave, with recordings of it being a source of income even before 1633 . It has been in function as a tourist cave ever since, but the visits diminished due to the vicinity of the Postojna Cave and Škocjan Caves which quickly established their reputation as leading cave destinations in Slovenia. In 1963, the cave was equipped with electric illumination by the local caving society, which manages the cave. Nowadays one of the most significant cultural event in Slovenia, the Vilenica International Literary Festival, is being organized in the cave every year since 1986 . The cave has $841 \mathrm{~m}$ of passages [26] with about $450 \mathrm{~m}$ of tourist paths.

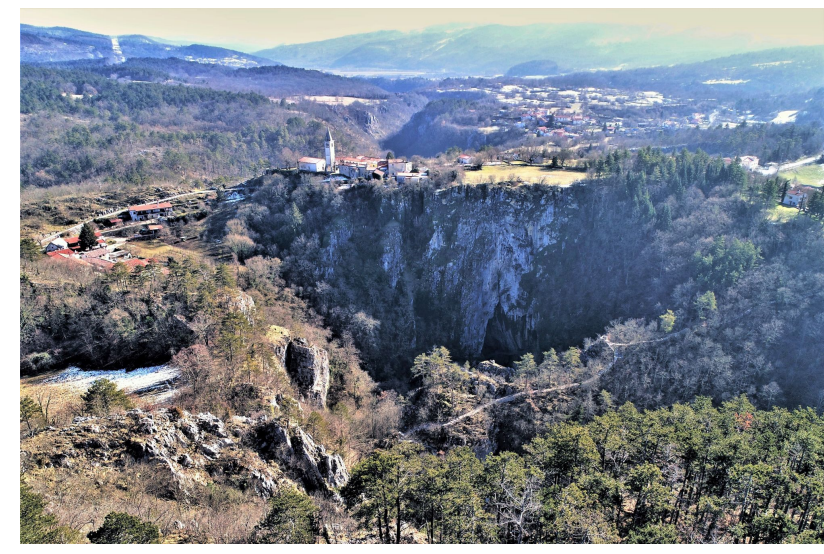

Figure 3: A collapse doline at Matavun settlement (SW Slovenia) above Škocjan Caves, one of the most attractive tourist caves in Slovenia.

The Vilenica Cave is under the management of a local caving society (Sežana Caving Society), and has around 11,500 tourist visits per year [5, 22].

The Županova Cave is located west from the Radensko (karst) Polje in central Slovenia near Velike Lipljenje settlement. The cave was discovered in 1926 and has $710 \mathrm{~m}$ of passages mostly consisting of large halls [26]. The cave is famous for its flowstone formations and the annual descend of visitors through a pit that used to be the first known entrance. The proximity of Ljubljana City $(20 \mathrm{~km})$ gives opportunities for future tourist development, focusing nowadays on individual guests and groups (e.g., school groups). The Županova Cave is under the management of a local tourist society (Grosuplje Tourist and Environmental Society) and has around 5,300 tourist visits per year [5].

\subsection{Assessment of geodiversity, geoheritage and geotourism}

The assessment of geodiversity and geoheritage is related to comprehensive nature protection and better management of protected areas [31-36].

In Slovenia, the assessment of geodiversity and geoheritage was carried out relatively early, and the first studies used simple numerical methods to define the degree of landscape attractiveness [37]. The most systematic geosite assessment analyses were carried out in the Alps, around Lake Bled [38], and in the Triglav Lakes Valley in Triglav National Park [39]. Some analyses focused on a single geomorphological or hydrological form, such as waterfalls [40], or on the loss of geoheritage due to geomorphic processes [41]. Recent studies have primarily focused 
on the Dinaric Mountains, where analyses of geodiversity hotspots were carried out in the Rakov Škocjan Nature Park [42], the Škocjan Caves Regional Park [43], and the Upper Pivka Basin [44]. Some recent papers also focused on urban area geosite assessment in Slovenia [45].

Another aspect, beside geodiversity and geoheritage assessment, is the assessment of geotourism destinations. According to Zorn et al. [6, 46] Slovenia is the cradle of karst geotourism.

The most influential interpretation of the development of tourist areas was made by Butler [47]. His model, often referred to as Tourism Area Life Cycle (TALC), explains the development of a tourist destination undergoing six stages (exploration, involvement, development, consolidation, stagnation, and decline or rejuvenation). Beside Butler's [48], some later models were used in Slovenia by considering development of sustainable and green tourism like the St. Gallen model made by Beritelli et al. [49].

In this study, we tested the methodology based on the "Modified Geosite Assessment Model" (M-GAM), first introduced by Tomić and Božić [23], which represents a modification of GAM model introduced by Vujičić et al. [50]. The value of the GAM model consists of two key indicators: Main Values $(M V)$, addressing geosite's natural characteristics and Additional Values ( $A V$ ) addressing humaninduced characteristics and it can be written as,

$$
G A M=M V+A V .
$$

The $M V$ include three groups of indicators: Scientific and educational values (VSE), Scenic and aesthetic values (VSA) and Protection values (VPr), with 12 subindicators $\left(S I M V_{i}\right)$ or,

$$
M V=V S E+V S A+V P r
$$

The $A V$ include two groups of indicators: Functional values (VFn) and Touristic values (VTr), with a total of 15 subindicators $\left(\operatorname{SIAV}_{j}\right)$ or,

$$
A V=V F n+V T r
$$

Here, $\operatorname{SIMV}_{i}$ represents the 12 subindicators of Main Values while $S I A V_{j}$ represents 15 subindicators of Additional Values. Based on the results assessment, a matrix of Main Values (horizontal axes) and Additional Values (vertical axes) is created (Fig. 6), where each geosite's final score is represented. The matrix is divided into nine zones that are indicated by $Z(i, j)(i, j=1,2,3)$, based on the grade the objects received in the previous evaluation process. Thus while discussing the results a level of Main and Additional Values (e.g., low, moderate, high) can be described.
While GAM model includes only the experts' opinion, M-GAM (Fig. 4) addresses the opinion of visitors as well. The visitors provide the rate of importance (Im) for all 27 subindicators in the assessment process, as

$$
I m=\frac{\sum_{k=1}^{K} I v_{k}}{K}
$$

where $I v_{k}$ is the numerical value given by each visitor for each subindicator and $K$ is the total number of visitors that rated the subindicators.

After each respondent rates the importance of every subindicator (from 0.00 to 1.00 ), the average value of each subindicator is calculated and the final value of that subindicator represents the importance factor. Afterwards, the value of the importance factor ( $\mathrm{Im}$ ) is multiplied by the value that was given by experts. In this way, the MGAM equation gives more objective results. Now, the value of the $M-G A M$ model can be written as,

$$
M-G A M=M V+A V,
$$

where,

$$
\begin{gathered}
M V=\sum_{i=1}^{n} I m_{i^{*} M V i} \\
A V=\sum_{j=1}^{n} I m_{j^{*} A V j}
\end{gathered}
$$

Here, $I m_{i}$ and $I m_{j}$ present the $I m$ factor value for each of the 12 subindicators of Main Values $(i=1, \ldots, 12)$ as well as the Im factor for each of the 15 subindicators of Additional Values $(j=1, \ldots, 15)$. In this way, the $M-G A M$ equation (5)-(7) gives more objective results than the GAM equation (1)-(3).

The structure and grades of indicators and subindicators remained the same as in previous GAM and M-GAM studies [15, 51-55], yet the approach in the study of cave geotourism in Slovenia was adapted by different measures (e.g., online questionnaire).

Two different sets of online questionnaires were prepared, addressing experts and visitor's opinion. Some of the questions had to be adapted to refer to the particularities of a cave geosite (e.g., size of the cave). An online survey was conducted between June $1^{\text {st }} 2017$ and July $12^{\text {th }} 2017$. For the expert's opinion the managers of the caves were addressed, additionally some results had to be obtained from karst scientists. For addressing the general public, a survey with snowball sampling approach was released via email to: 1) geomorphology interest groups, 2) geography and history interest groups, 3) teacher interest groups; 4) Slovenian tourist organisation, 5) high-schools, 6) primary schools in the vicinity of tourist caves, 7 ) tourist-info 


\section{M-GAM}

\section{Main Values}
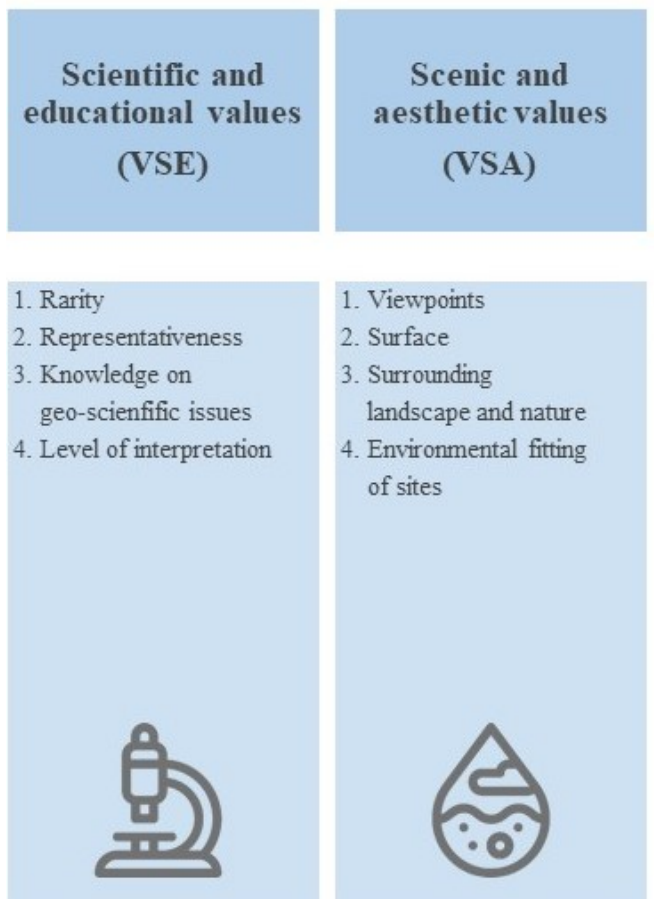

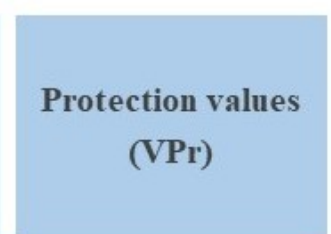

\section{Current condition \\ 2. Protection level \\ 3. Vulnerability \\ 4. Suitable number of visitors}

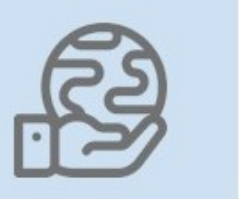

\section{Additional Values}

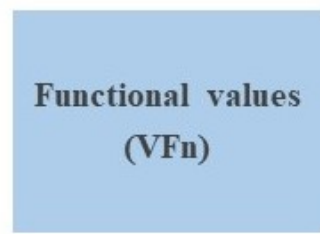

\section{Touristic values \\ (VTr)}

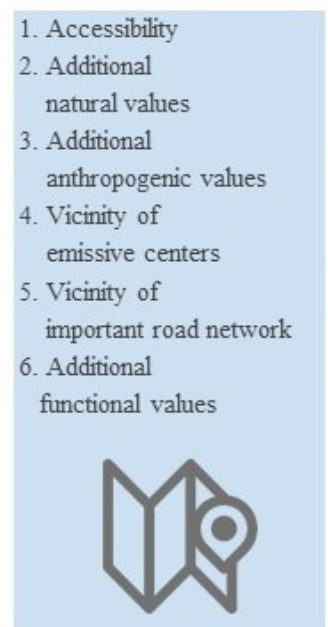

Figure 4: Schematic presentation of M-GAM model (adapted from [23]).

points in the vicinity of tourist caves, 8) municipalities in the vicinity of tourist caves and 9) social media.

Besides M-GAM model-oriented questions, the questionnaires included some demographic questions such as gender, age and education. Altogether 10 experts were included in the study, from which $80 \%$ were male and $20 \%$ female, in $80 \%$ belonging to the age group $30-49$ years and in $80 \%$ had tertiary second cycle of higher education or more. Among 331 tourists, $35 \%$ were male and $65 \%$ female, in $51 \%$ belonging to the age group $30-49$ years and in $77 \%$ had tertiary second cycle of higher education or more.

\section{Results and Discussion}

The first part of M-GAM results is actually an evaluation of geosites by GAM model. Results give experts insight (one expert per cave) in the overall geoheritage importance of an individual cave and their contemporary status within tourism development. Values given by experts $(0.00-1.00)$ for all 10 caves included in the study are listed in Table 2 (first ten columns), as well as total values. The individual total value is a product of the expert value and the importance factor (Im). The results were further aggregated for Main and Additional Values at the level of individual cave (Table 3).

The important upgrade of GAM model is given by the Importance factor (Im), which is not a measure for the evaluation of a geosite, but is a measure for the assessment of subindicators (27) evaluated by cave visitors. Thus, MGAM addresses the opinion of visitors from the aspect of subindicators. All 331 tourists provided the rate of importance (Im) in the assessment process. According to Im factor, the highest rated subindicators $(>0.80)$ are the most relevant and the most important for the assessment of cave geosite. The highest rated are Level of interpretation (0.94), Suitable number of visitors (0.89), Current condition (0.87), Vulnerability (0.82) and Protection level (0.81). In general, these rates express relatively high awareness of cave visitors regarding the protection of caves. The highest is also 
the average Im for some Main Values, e.g., Protection values (0.85) and Scientific and educational values (0.82). It is interesting that Main Value Scenic and aesthetic values are relatively low, on average only (0.60). It may be that the influence of the visiting experience itself and the adventure are more important to cave visitors than the aesthetic value.

The least important subindicator according to cave visitors is Hostelry service (0.20). The visitors of caves in Slovenia are mostly one day visitors traversing the country on their way to the final destination (e.g., foreign summer tourists from Germany, Italy, Austria etc. on their way to Croatian coastal destinations) and domestic guests (e.g., school groups, families) thus the accommodation services are not relevant for their visit of caves. In general, the average rating of subindicators from Additional Values are lower compared to Main Values, e.g., Functional indicators (0.45) and Tourist indicators (0.49).

According to Božić and Tomić [51] classification of geotourists among "general" (i.e. casual geotourists who visit geosites primarily for the purpose of pleasure and some limited intellectual stimulation) and "pure" (i.e. geotourists who purposefully select to visit geosites for the purpose of personal educational or intellectual improvement and enjoyment) geotourists, we can count Slovenian cave visitors to the latter group. In general, they give less importance to the human-induced values (such as tourist infrastructure) and give more importance to natural values of a geosite. They prefer geosites with basic tourism infrastructure and pay a lot of attention to the protection of geosites [51].

Main Values (Table 3; Fig. 5) are showing a joint, experts and tourists assessment of geoheritage and geotourism importance for an individual cave. The highest Main Values ( $>7$ ) were calculated for five caves: the Postojna Cave (7.96), the Pekel Cave (7.82), Škocjan Caves (7.45), the Županova Cave (7.29) and the Križna Cave (7.06). The three most visited caves (Table 1) are placed on first three places. The lowest Main Values ( $<5)$ were calculated for the Vilenica Cave (4.53).

Additional Values (Table 3; Fig. 5) are showing the same order for the Postojna Cave (6.74) and Škocjan Caves (6.51). Both reached Additional Values $>6$, which proves their dominance as the most visited and most popular caves in Slovenia. In contrary, the lowest Additional Values $(<5)$ were determined for four small and less visited caves: the Križna Cave (4.27), the Dimnice Cave (4.32), the Županova Cave (4.61) and the Snežna Cave (4.69). This means that at these destinations tourism infrastructure, promotion, interpretation etc. is not developed enough in comparison to leading tourist caves. The Križna Cave, the
Dimnice Cave and the Snežna Cave do not have electric illumination and almost none paved tourist paths through the cave. These facts can be also interpreted in a positive way by taking into account that these caves have remained preserved regarding infrastructural impacts (absence of lampenflora, preserved cave habitats, preserved cave sediment profiles and speleothems), thus being more interesting for scientific and educational purposes, as well as for the development of more sustainable tourism.

Upon M-GAM classification, two groups of Slovenian tourist caves are presented in the matrix: $Z_{22}$ and $Z_{21}$ (Fig. 6). The results show that there is more diversity within Main Values as within Additional Values.

A group of five $\mathrm{Z}_{22}$-classified caves reached in average the highest rates for Main and Additional Values. Considering individual indicators of M-GAM model (Figs. 5 and 6), both most visited tourist caves reached the highest Touristic values: the Postojna Cave (4.46) and Škocjan Caves (4.29). Among all caves, Škocjan Caves have the highest Scenic and aesthetic values (2.21) and the Postojna Cave reached the highest Protection values (3.38). Thus, they can be considered as hot spot destinations for "general" geotourists. The remaining three caves in the group have less developed tourism infrastructure, tourism products and promotion, thus it was expected that the Postojna Cave and Škocjan Caves would gain relatively higher $M-G A M$ values.

Since 2010 the Postojna Cave is managed by a private company, which is investing a lot in the development of new tourism products (e.g., adventure products), promotion of cave science (e.g., the birth of Proteus anguinus) and international promotion (e.g., by focusing on summer tourists in Croatian coastal destinations). Recently the "geosite area" has been extended and renamed to Postojna Cave Park destination, which includes surrounding natural karst phenomena (e.g., Predjama Cave, Pivka Cave), relevant cultural heritage sites (e.g., Predjama Cave Castle) and some supporting tourism products. The management of cave tourism in the context of a park destination has been previously used in nearby Škocjan Caves (the Škocjan Caves Regional Park) and proved to be an example of good practice from which also local tourism stakeholders and inhabitants can benefit.

Škocjan Caves are under the management of the Škocjan Caves Public Service Agency since 1996. The concentration of speleological and geomorphological features (e.g. blind valley, deep underground canyon, collapsed dolines, unroofed caves, dolines) lead to the inscription on the UNESCO World Heritage List in 1986 [43]. M-GAM values reflect the orientation in sustainable tourism. 


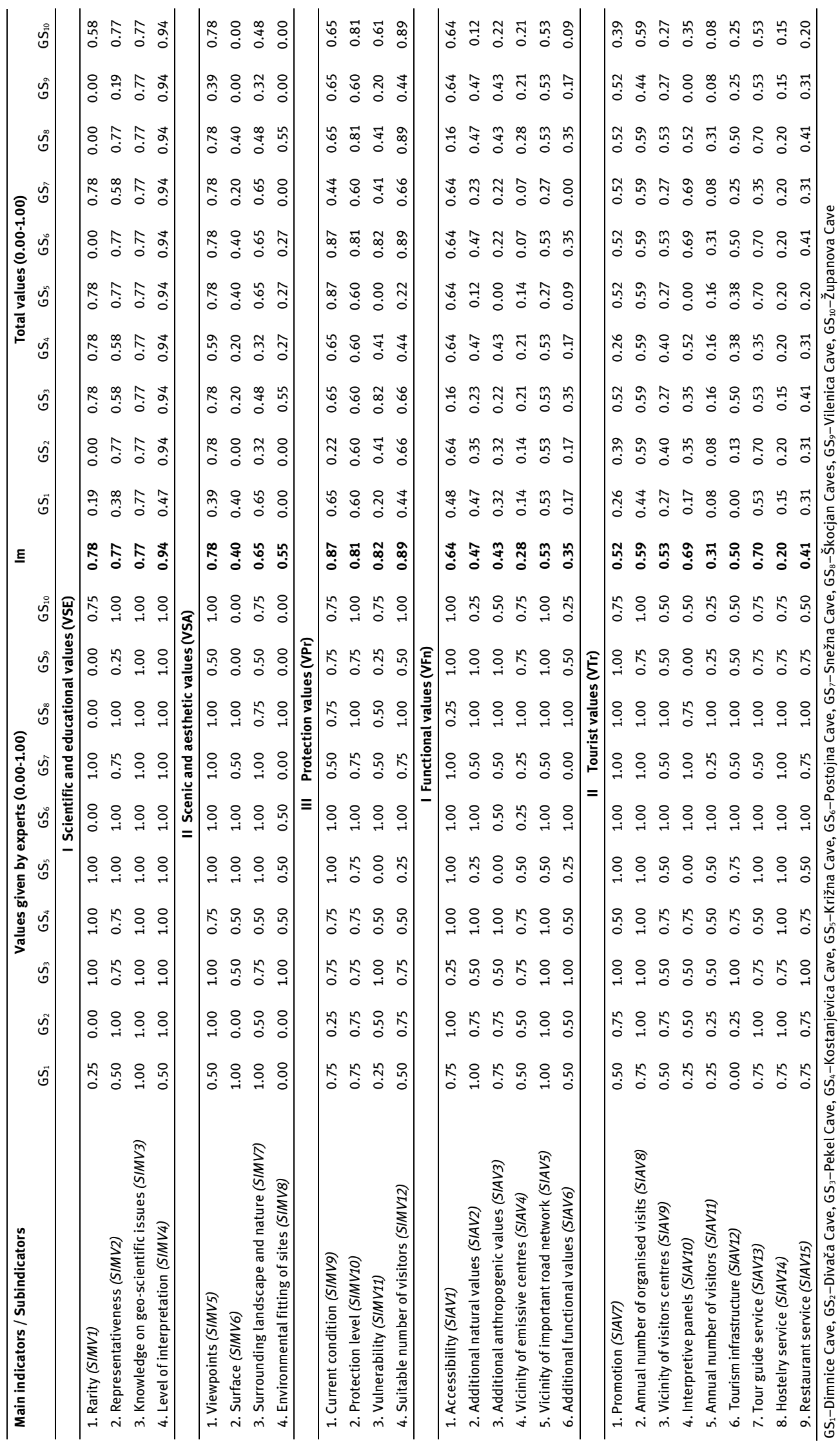




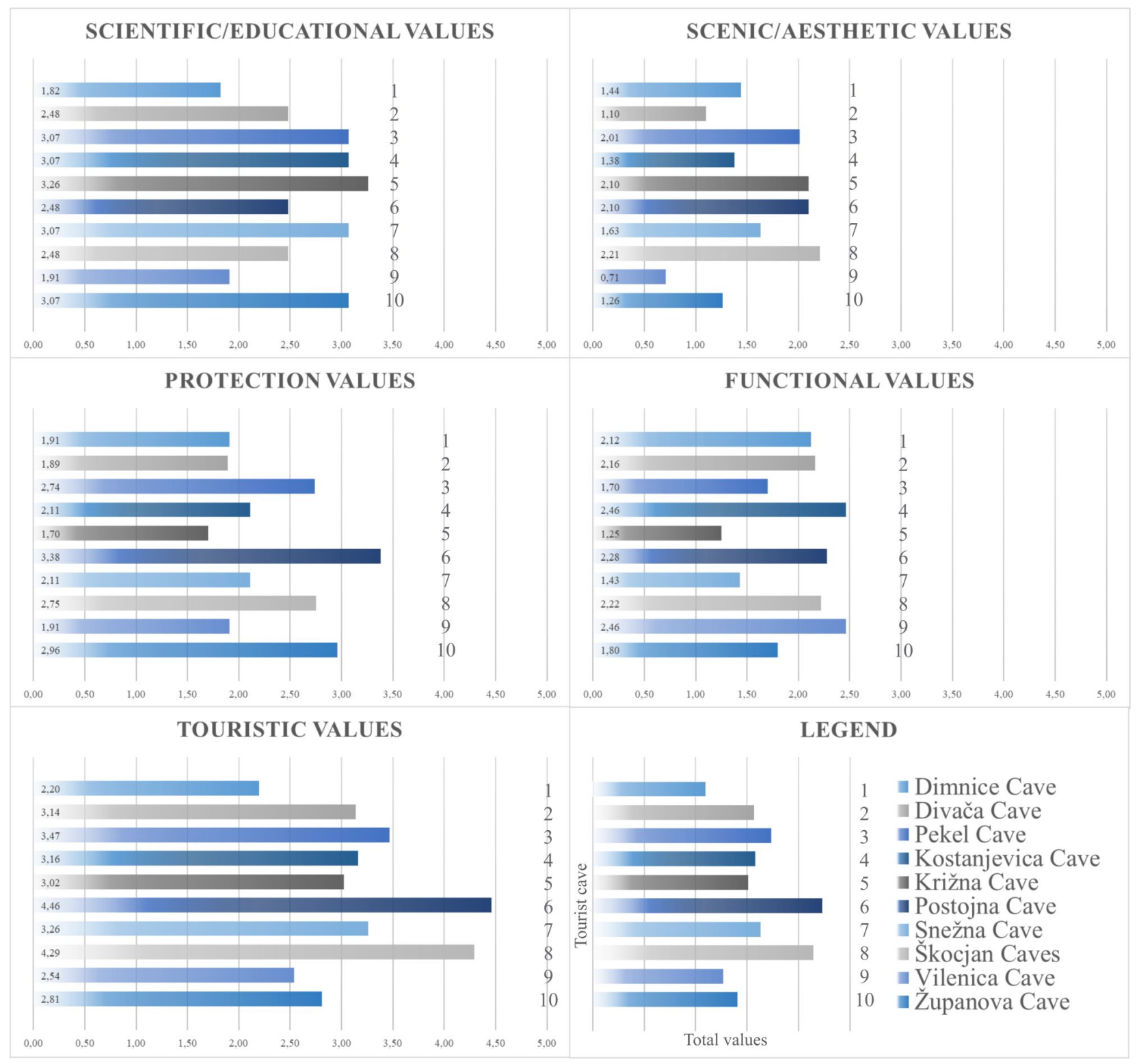

Figure 5: Distribution of results by indicators of M-GAM model.

Table 3: Overall assessment of geosite's characteristics in studied Slovenian tourist caves by using M-GAM model.

\begin{tabular}{lccccc}
\hline Geosite label & \multicolumn{2}{c}{ Main Values } & \multicolumn{4}{c}{ Additional Values } & Field \\
& $V S E+V S A+V p r$ & $\sum$ & $V F n+V T r$ & $\sum$ & \\
\hline $\mathrm{GS}_{1}$-Dimnice Cave & $1.82+1.44+1.91$ & 5.16 & $2.12+2.20$ & 4.32 & $\mathrm{Z}_{21}$ \\
$\mathrm{GS}_{2}$-Divača Cave & $2.48+1.10+1.89$ & 5.48 & $2.16+3.14$ & 5.30 & $\mathrm{Z}_{22}$ \\
$\mathrm{GS}_{3}$-Pekel Cave & $3.07+2.01+2.74$ & 7.82 & $1.70+3.47$ & 5.17 & $\mathrm{Z}_{22}$ \\
$\mathrm{GS}_{4}$-Kostanjevica Cave & $3.07+1.38+2.11$ & 6.56 & $2.46+3.16$ & 5.62 & $\mathrm{Z}_{22}$ \\
$\mathrm{GS}_{5}$-Križna Cave & $3.26+2.10+1.70$ & 7.06 & $1.25+3.02$ & 4.27 & $\mathrm{Z}_{21}$ \\
$\mathrm{GS}_{6}$-Postojna Cave & $2.48+2.10+3.38$ & 7.96 & $2.28+4.46$ & 6.74 & $\mathrm{Z}_{22}$ \\
$\mathrm{GS}_{7}$-Snežna Cave & $3.07+1.63+2.11$ & 6.81 & $1.43+3.26$ & 4.69 & $\mathrm{Z}_{21}$ \\
$\mathrm{GS}_{8}$-Škocjan Caves & $2.48+2.21+2.75$ & 7.45 & $2.22+4.29$ & 6.51 & $\mathrm{Z}_{22}$ \\
$\mathrm{GS}_{9}$-Vilenica Cave & $1.91+0.71+1.91$ & 4.53 & $2.46+2.54$ & 5.00 & $\mathrm{Z}_{22}$ \\
$\mathrm{GS}_{10}-$ Županova Cave & $3.07+1.26+2.96$ & 7.29 & $1.80+2.81$ & 4.61 & $\mathrm{Z}_{21}$ \\
\hline Mean & - & 6.61 & - & $\mathbf{5 . 2 2}$ & - \\
\hline
\end{tabular}

The further increase of cave visitors in the Postojna Cave and Škocjan Caves could also have a negative impact on karst phenomena such as increase of temperature and carbon dioxide levels [56-58], raise of airborne bacteria in a cave [59] and aerosol particles [60]. Further development of geotourism, thus have to consider the carrying capacity of these geosite destinations. The main tourism concern of both leading tourist caves is to provide such tourism products that will diminish negative effects of cave tourism (e.g. optimization of tourist groups, minimize the effects of renovation works) and extend the duration of tourists stay in the destination, e.g., through the connection with other tourism stakeholders. 


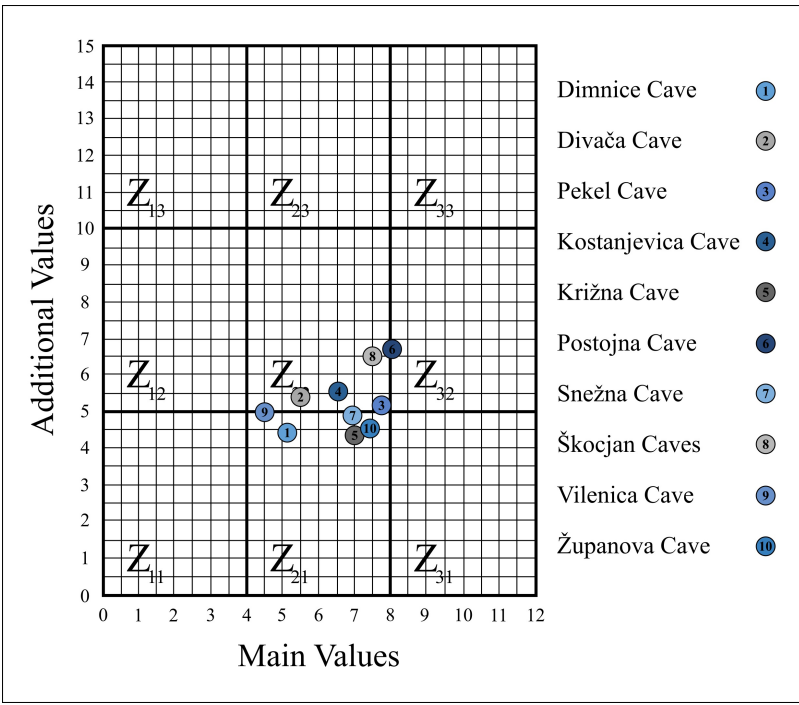

Figure 6: Matrix distribution of tourist caves in Slovenia according to Main and Additional Values of the M-GAM model.

The Kostanjevica Cave is under the management of a local caving club and according to M-GAM Additional Values, the cave is rated as third (5.62) and first among Functional values (2.46) (Figs. 5 and 6). Although distant from "classical karst" destinations in SW Slovenia, this cave has a relatively long history of cave tourism. Being located near the town of Kostanjevica na Krki with rich cultural and natural heritage, it is an addition to the local tourist offer. One of the main drivers for higher number of visitors is the proximity of the Čatež Spa, from where tourists make a one-day trip to Kostanjevica na Krki. Relatively low Protection values derive from the fact, that some parts of tourist paths affected the morphology of cave passages.

The Divača Cave is under the management of a local caving society. $M$ - GAM values express relatively high $A d$ ditional Values (5.30), above average (Table 3). The vicinity of Škocjan Caves offers opportunities for common tourism products and promotion. The opportunity is also in an emerging UNESCO Geopark Kras that will connect local communities (municipalities) of the region. The particularity of the cave is in its rich history of interesting and famous visitors.

The Pekel Cave is under the management of a local tourist society that also manages other tourist attractions in the vicinity. As the rest of $Z_{22}$ caves, the Pekel Cave has high Scientific and educational values (3.07) as well as Scenic and aesthetic values (2.01), yet there is a need for the improvement of Additional Values. Investments in tourism infrastructure and promotion would improve the development of this geotourism destination. Another opportunity is the establishment of a broader geotourism park destina- tion with the inclusion of the cave, as is the example of the leading tourist caves.

A group of five $Z_{21}$-classified caves reached the highest rates for Main Values but lower for Additional Values. Accordingly, these caves should take an advantage of having good natural predispositions and are not yet damaged by human impacts. They should become hot spot destinations for "pure" geotourists that do not demand welldeveloped tourism infrastructure. The Županova Cave is in the second place regarding Protection values (2.96), while the Križna Cave is the most valued Scientific and educational cave in Slovenia (3.26).

Although, other three caves did not reach important $M$-GAM values, they are important regarding some specific karst phenomena. The Snežna Cave is one amongst 60 ice caves in Slovenia [26] and as such an important site for the reconstruction of paleoenvironment. Further development of these speleodestinations should be based on small groups of visitors led by educated local tourist guides.

The Vilenica Cave and the Dimnice Cave are under the management of local caving societies and have the potential to be included in the future Geopark Kras. Thus, their primary focus should be in the integration into this geopark. The Vilenica Cave has been known as the first tourist cave in the world. Over thirty years, the Vilenica Cave has been hosting the Vilenica International Literary Festival. The Dimnice Cave is famous for its mist that due to the circulation of warmer air in the colder period of the year appears at the entrance.

Similar study was recently performed in Serbia [55]. In comparison with Serbian tourist caves, Slovenian tourist caves reached higher Additional Values, which may be connected with human interventions and the level of tourism infrastructure. This is a consequence of longer cave tourism tradition and the vicinity of bigger tourist destinations and especially the direct connection to main tourist flows from Western and Central Europe towards the Mediterranean (Adriatic Sea).

By comparing two matrices (Fig. 7) it is evident that $Z_{21}$ and $Z_{22}$ are the only two fields in the matrix that were, by now, relevant for studied destinations.

\section{Conclusion}

Geotourism destinations included in the study experienced very diverse development processes. The reason for this is the influence of very heterogeneous factors. The aim was to recognize the level of the diversity in geotourism development and to define the weaknesses and opportunities of smaller less developed touristic caves in relation 


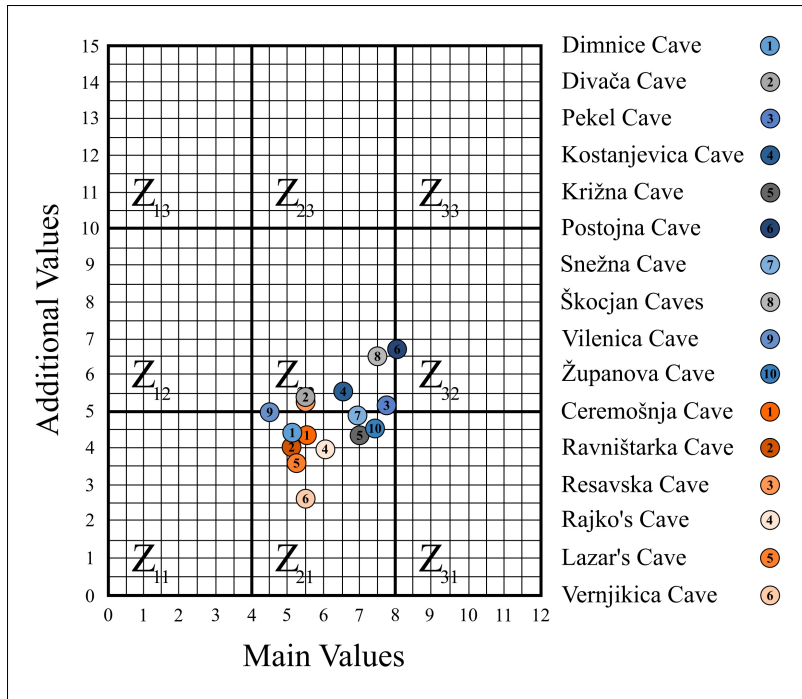

Figure 7: Matrix distribution of Slovenian (in blueish and greyish colours) and Serbian tourist caves (reddish colours; adapted from [55]) according to Main and Additional Values of the M-GAM model.

to already developed cave tourism destinations (e.g., the Postojna Cave, Škocjan Caves).

According to M-GAM, cave tourists in Slovenia are more "pure" than "general" geotourists as they give much less importance to the human-induced values and they mostly appreciate the natural values of a geosite. They prefer geosites without major tourism infrastructure (only basic) and pay more attention to the protection of these sites.

By using the M-GAM model, we proved the leading geotourism role of the Postojna Cave and Škocjan Caves. However, we expected that both caves would be ranked higher in the matrix. Considering the number of visitors, developed of tourism infrastructure and especially high scientific and world geoheritage value (e.g., UNESCO), we would expect the position from $Z_{31}$ to $Z_{33}$ which would indicate high Main Values. According to this, some other evaluation models should be tested for studied caves and compared with the present results. Nevertheless, the good practice of Škocjan Caves that are managed within a regional park that includes many karst geosites, should be transmitted to other caves, especially those that are currently managed by local cave societies or local tourist societies and should be included a broader geo-destination, e.g., protected area, coastal destination, geopark.

Results of the study presented some weaknesses of individual tourist caves (e.g., interpretative boards, poor promotion) that have to be addressed by the managers of tourist caves in order to properly accommodate the expectations of visitors.

\section{References}

[1] Hose T.A., Selling the story of Britain's stone. Env. Interpret, 1995, 10 (2), 16-17

[2] Hose T.A., Evaluating interpretation at Hunstanton. Earth Heritage, 1995, 4, 20

[3] Cardozo Moreira J., Neto de Carvalho C., Worldwide speleotourism: approaches for economic and heritage sustainability. Tourism and Karst Areas, 2013, 6 (1), 4-8

[4] Anderson J., Caves and karst geotourism in Australia. In: Dowling R., Newsome D. (Eds.), Global Geotourism Perspectives. Goodfellow Publishers Ltd., Oxford, 2010, 49-66

[5] Gams I., Kras v Sloveniji v prostoru in času. Založba ZRC, Ljubljana, 2004

[6] Zorn M., Erhartič B., Komac B., La Slovénie, berceau du géotourism karstique. Kartologia, 2009, 54 (2), 1-10

[7] Erikstad L., History of geoconservation in Europe. Geological Society London Special Publications, 2008, 300 (1), 249-256, DOI: $10.1144 /$ SP300.19

[8] Brinkmann R., Garren S.J., Karst and sustainability. In: Van Beyen P.E. (Ed.), Karst Management. Springer Netherlands, Dordrecht, 2011, 361-378, DOI: 10.1007/978-94-007-1207-2_16

[9] Watson J., Hamilton-Smith E., Gillieson D., Kiernan K., Guidelines for Cave and Karst Protection. IUCN Publications Services Unit, Cambridge, 1997

[10] Cigna A.A., Environmental management of tourist caves. Environmental Geology, 1993, 21 (3), 173-180

[11] Baker A., Genty D., Environmental pressures on conserving cave speleothems: effects of changing surface land use and increased cave tourism. Journal of Environmental Management, 1998, 53, 165-175, DOI: 10.1006/jema.1998.0208

[12] Cigna A.A., Forti P., Caves: the most important geotouristic feature in the world. Touirsm and Karst Areas, 2013, 6 (1), 9-26

[13] Pavlovich K., The evolution and transformation of a tourism destination network: the Waitomo Caves, New Zealand. Tourism Management, 2003, 24, 203-216, DOI: 10.1016/S02615177(02)00056-0

[14] Lobo Santos H.A., Trajano E., de Alcântara Marinho M., Bichuette M.E., Basso Scaleante J.A., Furquim Scaleante O.A., Nazaré Rocha B., Villela Laterza F., Projection of tourist scenarios onto fragility maps: Framework for determination of provisional tourist carrying capacity in a Brazilian show cave. Tourism Management, 2013, 35, 234-243, DOI: 10.1016/j.tourman.2012.07.008

[15] Šebela S., Turk J., Sustainable use of the Predjama Cave (Slovenia) and possible scenarios related to anticipated major increases in tourist numbers. Tourism Management Perspectives, 2014, 10, 37-45, DOI: 10.1016/j.tmp.2014.01.002

[16] Zhang S., Jin Y., Tourism resources on karst \& caves in China. In: Proceedings of the ISCA 2nd Congress. Malaga, 1996, 111-119

[17] Cigna A.A., Burri E., Development, management and economy of show caves. International Journal of Speleology, 2000, 29 B (1/4), 1-27

[18] Forti P., Cigna A.A., Cave tourism in Italy: an overview. In: Kranjc A., Kranjc M. (Eds.). Cave tourism. Proceedings of International Symposium at 170 -anniversary of Postojnska jama. Postojna, 1989, 46-53

[19] Slovenian Strategy of Sustainable Growth. Ljubljana, 2017

[20] Batagelj M., Annual Report of Postojna Cave for the year 2016. 
Postojnska jama d.d., Postojna, 2017

[21] Ščuka S., Annual Report of Škocjan Caves for the year 2016. Škocjan Caves Regional Park, Škocjan, 2017

[22] Kranjc A., Zgodovina jamskega turizma. In: Luthar O., Dobrovoljc H., Fridl J., Mulec J., Pavšek M. (Eds.), Kras: trajnostni razvoj kraške pokrajine. Založba ZRC, Ljubljana, 2008, 281-286

[23] Tomić N., Božić S., A modified Geosite Assessment Model (MGAM) and its application on the Lazar Canyon area (Serbia). International Journal of Environmental Research, 2014, 8 (4), 1041-1052, DOI: 10.22059/ijer.2014.798

[24] Morel S., Povojna odkritja v Dimnicah. Naše jame, 1989, 31, 90 93

[25] Mihevc A., The age of karst relief in west Slovenia. Acta carsologica, 200736 (1), 35-44, DOI: 10.3986/ac.v36i1.206

[26] Cave Registry JZS, Data about registered caves in Slovenia. Caving association of Slovenia, Ljubljana, 2017

[27] Hudoklin A., Kostanjeviška jama in njeni raziskovalci. In: Hudoklin A. (Ed.), Kostanjeviška jama. Jamarski klub Novo mesto in Klub jamarjev Kostanjevica na Krki, Novo mesto, Kostanjevica, 2000, 6-61

[28] Postojna Cave, Reports on management of the Postojna Cave, 2017 https://www.postojnska-jama.eu/en/

[29] Häuselmann P., Mihevc A., Pruner P., Horáček I., Čermák S., Hercman H., Sahy D., Fiebig M., Zupan Hajna N., Bosák P., Snežna jama (Slovenia): Interdisciplinary dating of cave sediments and implication for landscape evolution. Geomorphology, 2015, 247, 10-24, DOI: 10.1016/j.geomorph.2014.12.034

[30] Arsenović D., Vpliv turizma na jamsko okolje. BSc Thesis, University of Ljubljana, Ljubljana, 2007

[31] Pralong J.-P., A method for assessing the touristic potential and use of geomorphological sites. Géomorphologie: Relief, Processus, Environnement, 2005, 11 (3), 189-196

[32] Hobléa F., Karstic geomorphosites: managing subterranean natural-cultural heritage sites. In: Reynard E., Coratza P., Regolini-Bissig G. (Eds.), Geomorphostites. Verlag Fredrich Pfeil, München, 2009, 189-200

[33] Reynard E., The assessment of geomorphosites. In: Reynard E., Coratza P., Regolini-Bissig G. (Eds.), Geomorphostites. Verlag Fredrich Pfeil, München, 2009, 63-71

[34] Cayla N., Les processus de construction de géotourisme alpin. Téoros. Revue de recherche en tourisme. 2010, 29 (2), 15-25, DOI: $10.7202 / 1024867 \mathrm{ar}$

[35] Tomić N., The Potential of Lazar Canyon (Serbia) as a Geotourism Destination: Inventory and Evaluation. Geographica Pannonica, 2011, 15 (3), 103-112, DOI: 10.5937/GeoPan1103103T

[36] Erhartič B., Zorn M., Geodiversity and geomorphosite research in Slovenia. Geografski vestnik, 2012, 84 (1), 51-63

[37] Orožen Adamič M., Kako naj vrednotimo pokrajino? Proteus, 1970, 33 (4), 152-156

[38] Erhartič B., Conserving geoheritage in Slovenia through geomorphosite mapping. In: Regolini-Bissig G., Reynard B. (Eds.), Mapping geoheritage. Institute de géographie, Université Lausanne, Laussane, 2010, 47-63

[39] Erhartič B., Geomorfološka dediščina v Dolini Triglavskih jezer. Založba ZRC, Ljubljana, 2012

[40] Erhartič B., Geomorphosite assessment. Acta geographica Slovenica 2010, 50 (2), 295-319, DOI: 10.3986/AGS50206

[41] Komac B., Zorn M., Erhartič B., Loss of natural heritage from the geomorphological perspective - Do geomorphic pro- cesses shape or destroy the natural heritage? Acta geographica Slovenica, 2011, 51 (2), 339-342, DOI: 10.3986/AGS51305

[42] Stepišnik U., Repe B., Identification of geodiversity hotspots on example of the Rakov Škocjan Landscape Park. Dela, 2015, 44, 45-62, DOI: 10.4312/dela.44.1.45-62

[43] Stepišnik U., Trenchovska A., A new quantitative model for comprehensive geodiversity evaluation: the Škocjan Caves Regional Park, Slovenia. Geoheritage, 2018, 10, 39-48, DOI: 10.1007/s12371-017-0216-5

[44] Trenchovska A., Stepišnik U., The quantitative geodiversity model applied on upper Pivka karst, Slovenia. In: Buzjak N., Paar D. (Eds.), Zbornik sažetaka, International conference "Geodiversity, geoheritage and geotourism in karst areas". Faculty of Science, University of Zagreb, Zagreb, 2017, 45-48

[45] Tičar J., Komac B., Zorn M., Ferk M., Hrvatin M., Ciglič R., From urban geodiversity to geoheritage: the case of Ljubljana (Slovenia). Quaestiones Geographicae, 2017, 36 (3), 37-50, DOI: 10.1515/quageo-2017-0023

[46] Zorn M., Erhartič B., Komac B., The beginnings of karst geotourism - karst geotourism in Slovenia. In: Giusti C. (Ed.), Geomorphosites 2009: Raising the Profile of Geomorphological Heritage through Iconography, Inventory and Promotion. Sorbonne Université, Paris, 2012, 348-355

[47] Butler R.W., The concept of a tourist area cycle of evolution: implications for management of resources. The Canadian Geographer/Le Géographe Canadien, 1980, 24 (1), 5-12, DOI: 10.1111/j.1541-0064.1980.tb00970.x

[48] Cigale D., Development patterns of Slovene tourist destinations. Geografski vestnik, 2012, 84 (1), 187-197.

[49] Beritelli P., Bieger T., Laesser C., The new frontiers of destination management: Applying variable geometry as a functionbased approach. Journal of Travel Research, 2014, 53(4), 403417, DOI: $10.1177 / 0047287513506298$

[50] Vujičić M.D., Vasiljević D.A., Marković S.B., Hose T.A., Lukić T., Hadžić O., Janićević S., Preliminary geosite assessment model (gam) and its application on Fruška gora mountain, potential geotourism destination of Serbia. Acta geographica Slovenica, 2011, 51 (2), 361-377, DOI: 10.3986/AGS51303

[51] Božić S., Tomić N., Canyons and gorges as potential geotourism destinations in Serbia: Comparative analysis from two perspectives - general geotourists' and pure geotourists'. Open Geosciences, 2015, 7 (1), 531-546, DOI: 10.1515/geo-2015-0040

[52] Tomić N., Marković S.B, Korać M., Mrđić N., Hose T.A., Vasiljević D., Jovičić M., Gavrilov M.B., Exposing mammoths: From loess research discovery to public palaeontological park. Quaternary International, 2015, 372, 142-150, DOI: 10.1016/j.quaint.2014.12.026

[53] Boškov J., Kotrla S., Jovanović M., Tomić N., Lukić T., Rvović I., Application of the preliminary geosite assessment model (GAM): the case of the Bela Crkva municipality (Vojvodina, North Serbia). Geographica Pannonica, 2015, 19 (3), 146-152, DOI: 10.5937/GeoPan1503146B

[54] Petrović M.D., Lukić D.M., Radovanović M., Vujko A., Gajić T., Vuković D., Urban geosites as an alternative geotourism destination - Evidence from Belgrade. Open Geosciences, 2017, 9, 442-456, DOI: 10.1515/geo-2017-0034

[55] Tomić N., Antić A., Marković S.B., Đorđević T., Zorn M., Breg Valjavec M., Exploring the Potential for Speleotourism Development in Eastern Serbia. Geoheritage (in press). DOI: 10.1007/s12371-018-0288-x 
[56] Šebela S., Turk J., Pipan T., Cave micro-climate and tourism: towards 200 years (1819-2015) at Postojnska jama (Slovenia). Cave and Karst Science, 2015, 42 (2), 78-85

[57] Debevec V., Peric B., Šturm S., Zorman T., Jovanovič P., Škocjan Caves, Slovenia: an integrative approach to the management of a World Heritage Site. In: Parise M., Gabrovšek F., Kaufmann G., Ravbar N. (Eds.), Advances in Karst Research: Theory, Fieldwork and Applications. Geological Society of London, London, 2018, 411-429, DOI: $10.1144 /$ SP466.14
[58] Prelovšek M., Šebela S., Turk J., Carbon dioxide in Postojna Cave (Slovenia): spatial distribution, seasonal dynamics and evaluation of plausible sources and sinks. Environmental Earth Sciences, 2018, 77, 289, DOI: 10.1007/s12665-018-7459-6

[59] Mulec J., Oarga-Mulec A., Šturm S., Tomazin R., Matos T., Spacio-temporal distribution and tourist impact on airborne bacteria in a cave (Škocjan Caves, Slovenia). Diversity, 2017, 9 (3), 28, DOI: $10.3390 / \mathrm{d} 9030028$

[60] Grgić I., Iskra I., Podkrajšek B., Debevec Gerjevič V., Measurements of aerosol particles in the Škocjan Caves, Slovenia. Environmental Science and Pollution Research International, 2014, 21 (3), 1915-1923, DOI: 10.1007/s11356-013-2080-4 